\title{
Antioxidative Defence Mechanisms in Tomato (Lycopersicum esculentum L.) Plants Sprayed with Different Pesticides and Boron compounds
}

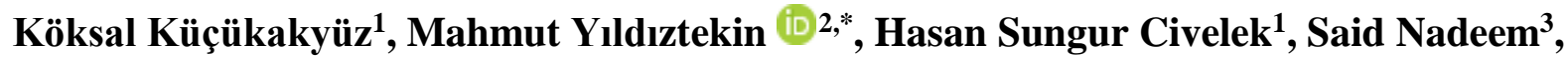 Atilla Levent Tuna ${ }^{1}$}

\author{
${ }^{1}$ Department of Biology, Faculty of Science, Muğla Sitk1 Kocman University, Muğla-48000, Muğla, Turkey \\ ${ }^{2}$ Department of Herbal and Animal Production, Koycegiz Vocational School, Muğla Sitkı Kocman University, \\ Köyceğiz-48800, Muğla, Turkey \\ ${ }^{3}$ Department of Chemistry, Faculty of Science, Muğla Sitk1 Kocman University, Muğla-48000, Muğla, Turkey
}

\begin{abstract}
Oxidative stress was investigated in Lycopersicum esculentum L. by applying various pesticides and boron compounds for two years, near OrtacaMuğla. The field sections were treated separately by commercial pesticides and boron compounds i.e. tarimbor (TB), boric acid (BA), laser (LA), zoom (ZO) and admiral (AD). During first year, boric acid (BA-1) caused highest increase in total chlorophyll (TCh) content (158.41 $\left.\mu \mathrm{g} \mathrm{g}^{-1}\right)$ while the second dose (BA-2) decreased it $\left(103.11 \mu \mathrm{g} \mathrm{g}^{-1}\right)$. During second year, higher doses of tarimbor $\left(236.49 \mu \mathrm{g} \mathrm{g}^{-1}\right)$ caused increase in total chlorophyll (TCh) while ZO treatment decreased it (142.55 $\mu \mathrm{g} \mathrm{g}^{-1}$ ) (control: $149.55 \mu \mathrm{g} \mathrm{g}^{-1}$ ). TB-1 caused the highest increase in proline content $\left(33.52 \mathrm{nmol} \mathrm{g}^{-1}\right)$ while highest reduction was observed in boric acid (BA-2) (22.51 $\left.\mathrm{nmol} \mathrm{g} \mathrm{g}^{-1}\right)$ as compared to control group $\left(26.77 \mathrm{nmol} \mathrm{g}^{-1}\right)$. During the first year, an increase of boric acid and tarimbor concentrations decreased malonaldehyde (MDA) while during the second year, both increases and decreases were observed in the MDA amount. Highest superoxide dismutase (SOD) amount was found in the first year $\mathrm{ZO}$ treated plants i.e. 70.35 unit $\mathrm{SOD} / \mathrm{mg}$ protein while $\mathrm{TB}-1$ treatment caused the highest decrease in the SOD amount i.e. 35.21 unit SOD/mg protein (control: 45.23 unit SOD/mg protein).
\end{abstract}

\section{ARTICLE HISTORY}

Received: 30 March 2018

Revised: 16 July 2018

Accepted: 20 July 2018

\section{KEYWORDS}

Lycopersicum esculentum L., Antioxidative enzymes, Malonaldehyde MDA, Boron stress, Pesticides

\section{INTRODUCTION}

Oxidative stress can be defined as an imbalance between the production of free radicals (reactive oxygen species) and antioxidant defenses that can be natural or anthropogenic. The latter include pesticides, air pollutants and heavy metals [1]. Pesticides have a crucial role in the pest management and control of plant diseases. However, its excessive use particularly in terms of their application at high doses may increase especially in developing countries. Thus, it is important to optimize their use for safeguarding the consumers and producers as well as reducing environmental hazards [2,3]. Pesticide use is very common in vegetable production in glasshouse conditions to protect pest-induced damage. However, the use of pesticide at high rates may cause toxicity problem, which can deleteriously affect plant growth and development.

CONTACT: Mahmut Ylldıztekin $\bigotimes$ mahmutyildiztekin@mu.edu.tr $\equiv$ Department of Herbal and Animal Production, Koycegiz Vocational School, Muğla Sitkı Kocman University, Köyceğiz-48800, Muğla, Turkey 
Foliar applications of pesticides may negatively affect leaf photosynthesis by partially blocking stomatal pores which allow exchange of gases. Therefore, reduction in photosynthetic activity can delay time of fruit harvesting or affect adversely fruit quality, as well as visible damage due to chemical toxicity [4]. The pesticides used in the present experiment such as thiamethoxam and acetamiprid belong to the neonicotinoid insecticide group. They were introduced worldwide about a decade ago as they have lower toxicity and high activity against pests and insects [5,6]. Abamectin is a macrocyclic lactone and is a major fermentation component of avermectins, natural products produced from the soil bacterium Streptomyces avermitilis. It shows insecticidal, acaricidal and nematicidal activities [7]. Pyriproxyfen is known as an insect growth regulator (IGR). It is an analogue of a juvenile hormone (JHA). It is being widely used as an insecticide for the control of different pests [8,9]. Plants have a well-developed antioxidative machinery to prevent cellular membranes from toxic effects caused by reactive oxygen species [10,11]. It is reported that reactive-oxygen species (ROS) are responsible for various stress-induced damages to cellular structures. It is widely accepted that chemical toxicity results in oxidative stress due to the production of ROS [12-15]. Under stress conditions plants may alter the activities of ROS scavenging enzymes, such as superoxide dismutase (SOD; EC1.15.1.1) and catalase (CAT; EC1.11.1.6) [16]. To date, there seems to be no knowledge available in the literature on functioning of antioxidative defense machinery to pesticides, such as abamectin, thiamethoxam, pyriproxyfen and acetamiprid. Thus, we hypothesized that application of different pesticides at high doses could cause oxidative stress and hence regulate antioxidative defense system in tomato plants. Therefore, in the present study we examined the effects of pesticides sprayed at higher doses on key plant growth attributes, production of ROS and activities of antioxidant enzymes in the leaves of tomato plants.

Boron is an important microelement in plant nutrition. The main functions of boron relate to cell wall strength and development, cell division, fruit and seed development, sugar transport, and hormone development. Plants uptake boron in slight amount whereas its higher level is toxic to plants [17]. Boron-deficient tissues are brittle or fragile, while plants grown on high boron levels may have unusually flexible or resilient tissues [18].

Herein we report the study of various boron containing fertilizer (boric acid and tarimbor), and pesticides on Lycopersicum esculentum. Unlike literature reports, we did not found the high amount of boron as toxic. We used three types of pesticides i.e. Admiral, Laser and Zoom trademarks to study the changes in the physiology and biochemistry of the stated plant.

\section{MATERIAL AND METHODS}

The experiments were performed at the fields located in Mugla province (district Ortaca). The field was divided into various blocks that were divided into control, zoom (etoxazole, sumitomo), laser (Spinosad, Dow Agro Sciences), admiral (Pyripyroxyfen, sumitomo), boric acid and tarimbor randomly. The stated insecticides and acaricide were used according to the suggested amount of manufacturers. Tarimbor $\left(\mathrm{Na}_{2} \mathrm{~B}_{8} \mathrm{O}_{13} .4 \mathrm{H}_{2} \mathrm{O}\right)$ and boric acids were sprayed on the plants. The blocks were separated from each other's by a separating bands (SB). Total 30 blocks as a whole were studied.

\section{Plant culture and treatments}

The study was performed for two years on tomatoes (first year Lycopersicum esculentum var. Bestona F1, second year L. esculentum var. Manyla F1). First three weeks, only the development of plant was observed. After that time, boron and pesticide treatments were applied depending upon the procedure of experiment. On the $14^{\text {th }}$ day of the treatments, 30 leaves were collected from each block of plants for physiological studies. For biochemical studies, 20 leaves were collected from each block separately. The leaves were stored in the 
refrigerator immediately after plucking, till they arrive at the lab. Leaves were stored at $-20{ }^{\circ} \mathrm{C}$ in the lab freezer till further studies. Tables 1 and 2 shows the experimental design of the field where the study was performed.

Table 1. Experimental design of the field (2010) first year

\begin{tabular}{cccccccccc}
\hline & \multicolumn{8}{c}{ Entrance } \\
ZO & SB & BA (1-1) & SB & TB (2-1) & SB & AD & SB & AD & SB \\
SB & BA (2-1) & SB & C & SB & ZO & SB & TB (1-3) & SB & BA (1-2) \\
TB (3-3) & SB & LA & SB & BA (2-3) & SB & LA & SB & C & SB \\
SB & ZO & SB & TB (3-1) & SB & AD & SB & BA (3-3) & SB & TB (2-2) \\
TB (1-1) & SB & C & SB & BA (1-2) & SB & TB (3-2) & SB & BA (1-3) & SB \\
SB & BA (3-2) & SB & TB (2-3) & SB & LA & SB & BA (2-2) & SB & TB (1-2) \\
\hline
\end{tabular}

SB: Separation Band; C: Control irrigation water; BA: Boric acid; BA-1: 2ppm; BA-2: 5 ppm; BA-3: 10 ppm; TB-1: 20 ppm; TB: Tarimbor; TB-2: 40 ppm; TB-3: 80 ppm; ZO: Zoom 35 mL /100 L; LA: Laser, 30 mL/100 L; AD: Admiral $50 \mathrm{~mL} / 100 \mathrm{~L}$

Table 2. Experimental design of the field (2011) second year

\begin{tabular}{|c|c|c|}
\hline BA 3-1 & \multirow{29}{*}{$\begin{array}{l}\text { ठ } \\
\text { : } \\
\text { 氚 }\end{array}$} & TB 1-1 \\
\hline$\overline{S B}$ & & $S B$ \\
\hline TB 3-2 & & BA 2-2 \\
\hline$S B$ & & $S B$ \\
\hline TB 2-1 & & TB 3-3 \\
\hline$S B$ & & $S B$ \\
\hline C-2 & & $\mathrm{AD}$ \\
\hline$S B$ & & $S B$ \\
\hline LA & & ZO-1 \\
\hline$S B$ & & $S B$ \\
\hline TB 1-2 & & BA $1-1$ \\
\hline$S B$ & & $S B$ \\
\hline BA 3-3 & & TB 2-2 \\
\hline$S B$ & & $S B$ \\
\hline C-1 & & BA $1-3$ \\
\hline$S B$ & & $S B$ \\
\hline $\mathrm{ZO}$ & & BA $2-1$ \\
\hline$S B$ & & $S B$ \\
\hline BA 3-2 & & TB $1-3$ \\
\hline$S B$ & & $S B$ \\
\hline LA & & $\mathrm{AD}$ \\
\hline$S B$ & & $S B$ \\
\hline TB 3-1 & & $\mathrm{ZO}$ \\
\hline$S B$ & & $S B$ \\
\hline BA $1-2$ & & C-3 \\
\hline$S B$ & & $S B$ \\
\hline TB 2-3 & & LA \\
\hline$S B$ & & $S B$ \\
\hline BA 2-3 & & $\mathrm{AD}$ \\
\hline
\end{tabular}

SB: Separation Band; C: Control irrigation water; BA: Boric acid; BA-1: 2ppm; BA-2: 5 ppm; BA-3: 10 ppm; TB-1: 20 ppm; TB: Tarimbor; TB-2: 40 ppm; TB-3: 80 ppm; ZO: Zoom 35 mL /100 L; LA: Laser, 30 mL/100 L; AD: Admiral $50 \mathrm{~mL} / 100 \mathrm{~L}$

\section{Chlorophyll determination}

Chlorophyll content was determined by the standard procedure of Strain and Svec [19] with slight modification. 


\section{Leaffree proline content}

Leaf free proline content was determined by the procedure developed by Bates et al. [20]. Antioxidant enzymes and malondialdehyde

Fresh leaf material $(500 \mathrm{mg})$ was well grounded in sodium phosphoate buffer (50 $\mathrm{mM})$ that contained $1 \%$ soluble polyvinyl pyrrolidine. Superoxide dismutase (SOD) was determined according to Giannopolitis and Reis [21], and Cakmak et al. [22]. Catalase activity was determined by the procedure of Bergmeyer [23]. Ascorbate peroxidase activity was determined by the Nakano and Asada [24] procedure. POD was performed according to Herzog and Fahimi [25]. The Bradford [26] protocol was employed to estimate total soluble proteins.

\section{Leaf malondialdehyde (MDA) contents}

MDA content was determined according to Madhava Rao and Stresty [27] procedure.

\section{Statistical analysis}

The obtained data was subjected to SPSS (v. 14) analytical software to work out variance analysis. Significant differences among mean values were assessed using LSD test at $\mathrm{p} \leq 5 \%$.

\section{Soil characteristic analysis}

The soil samples were analyzed for $\mathrm{Zn}, \mathrm{Fe}$ and $\mathrm{Cu}$ according to DTPA [28]. K, Ca and $\mathrm{Mg}$ concentrations were determined according to Thomas [29] procedure. Na concentrations were analyzed by Knudsen et al. [30]. These analyses were performed using atomic absorption at $1 \mathrm{~N}$ concatenation with neutral ammonium acetate. Water soluble phosphorus was determined by Bingham [31] colorimetric spectroscopic procedure. Plant consumable boron was determined by $0.01 \mathrm{M}$ manitol $+\mathrm{CaCl}_{2}$ extraction by ICP-AES instrument [32]. $\mathrm{pH}$ and $\mathrm{EC}$ were determined by $\mathrm{pH}-\mathrm{EC}$ meter.

\section{Yield analysis}

Tomato fruit production was analyzed on weekly bases from the beginning of the crops fruit giving to the end of the harvest for two years.

\section{RESULTS AND DISCUSSION}

As stated in the method section, the study was performed for two years. This study covers the chlorophyll, carotenoid, lipid peroxidation, proline, proteins analyses and antioxidative (superoxide dismutase: SOD, peroxidase: POD, ascorbate peroxidase: APOD, catalase: CAT) enzyme inhibition activities after the treatment of boron compounds (tarimbor and boric acid) and pesticides (Zoom, Laser and Admiral) over L. esculentum. The results were compared with the control group plant leaves on fresh weight basis $(\mathrm{FW})$.

\subsection{Total Chlorophyll (TCh) and carotenoid (Car) analysis}

Pesticides and boron treated L. esculentum showed a decrease in the chlorophyll amount during first year, while an increase was observed during the second (Table 3). After first year treatments, total chlorophyll (TCh) amount showed a decrease except the third dose of tarimbor (TB-3). Boric acid (BA-1) caused highest increase in the TCh $\left(158.41 \mu \mathrm{g} \mathrm{g}^{-1}, \mathrm{FW}\right)$ while least amount was observed in the second dose $\left(103.11 \mu \mathrm{g} \mathrm{g}^{-1}, \mathrm{FW}\right)$ of boric acid (BA-2) as compared to the control (136.85 $\mu \mathrm{g} \mathrm{g}^{-1}$, FW) (Figure 1).

During the second year, an increase was observed in the total chlorophyll amount except Zoom (ZO) treatment. Highest total chlorophyll increase was observed after the treatment of tarimbor $\left(236.49 \mu \mathrm{g} \mathrm{g}^{-1}, \mathrm{FW}\right)$ while $\mathrm{ZO}$ treatment decreased it $\left(142.55 \mu \mathrm{g} \mathrm{g}^{-1}, \mathrm{FW}\right)$; even less than the control $\left(149.55 \mu \mathrm{g} \mathrm{g}^{-1}, \mathrm{FW}\right)$. Carotenoids amount observed after the pesticides and 
boron treatments were statistically insignificant $(\mathrm{p} \leq 0.05)$. As a whole, they carotenoids were decreased during first year treatments while increased during second year (Figure 2).

Table 3. Effect of pesticides and different boron compounds on the total chlorophyll and carotenoid $\left(\mu \mathrm{g} \mathrm{g}^{-1} \mathrm{FW}\right.$ ) contents (year 2010\&2011)

\begin{tabular}{ccccc}
\hline \multirow{2}{*}{ Treatments } & \multicolumn{2}{c}{2010} & \multicolumn{2}{c}{2011} \\
\cline { 2 - 5 } & TChl & Car & TChl & Car \\
\hline C & $136.85 \mathrm{ab}$ & $15.21 \mathrm{ab}$ & $149.55 \mathrm{~b}$ & $23.84 \mathrm{bc}$ \\
BA-1 & $158.41 \mathrm{a}$ & $16.51 \mathrm{a}$ & $177.10 \mathrm{ab}$ & $25.77 \mathrm{abc}$ \\
BA-2 & $103.11 \mathrm{c}$ & $11.61 \mathrm{~b}$ & $221.46 \mathrm{ab}$ & $35.44 \mathrm{a}$ \\
BA-3 & $146.06 \mathrm{a}$ & $15.12 \mathrm{ab}$ & $193.65 \mathrm{ab}$ & $32.41 \mathrm{abc}$ \\
TB-1 & $131.75 \mathrm{ab}$ & $15.82 \mathrm{a}$ & $176.33 \mathrm{ab}$ & $26.54 \mathrm{abc}$ \\
TB-2 & $115.99 \mathrm{bc}$ & $12.32 \mathrm{ab}$ & $205.31 \mathrm{ab}$ & $31.76 \mathrm{abc}$ \\
TB-3 & $139.53 \mathrm{ab}$ & $15.07 \mathrm{ab}$ & $236.49 \mathrm{a}$ & $33.72 \mathrm{ab}$ \\
LA & $145.01 \mathrm{a}$ & $16.18 \mathrm{a}$ & $205.53 \mathrm{ab}$ & $30.97 \mathrm{abc}$ \\
ZO & $152.52 \mathrm{a}$ & $14.93 \mathrm{ab}$ & $142.55 \mathrm{~b}$ & $21.36 \mathrm{c}$ \\
AD & $153.53 \mathrm{a}$ & $14.81 \mathrm{ab}$ & $228.97 \mathrm{ab}$ & $31.47 \mathrm{abc}$ \\
\hline
\end{tabular}

Note: values followed by different letters, in the same column, are significantly different at $p \leq 0.05$.

While studying pear tree, Wang et al. [33] obtained similar results to our first year treatments. They subjected the plant to boron stress that decreased the chlorophyll A, chlorophyll B, carotenoids and chlorophyll A/B amounts. On the other hand, Tort et al. [34] treated Capsicum annuum L. with Captan fungicide with various doses $\left(2.5,5,7.5 \mathrm{~g} \mathrm{~L}^{-1}\right)$. They found an increase in the TCh and carotenoids (Car) after the prescribed dose; while increasing the concentration, decreased the TCh and Car. Öztürk and Tort [35] treatment cyprodinil fungicide at three different doses. TCh, chlorophyll A and B increased after first two doses while decreased after the third dose when compared to the control. Our results showed similarities with the reported ones. Oxidative stress can increase the chlorophyllase enzyme that will further decrease the leaves chlorophyll content [36].

\subsection{Proline and Lipid peroxidation (MDA) analysis}

Ten samples were analyzed for proline content where the first one was the control $L$. esculentum. During first year, boric acid treatment caused an increase in the proline amount with the increase in boron amount. On the contrast, an increase in the tarimbor amount decreased the proline amount. In pesticide treatments, $\mathrm{ZO}$ caused an increase while LA and AD caused a decreased in the proline amount. First treatment of tarimbor (TB-1) caused the highest increase in proline amount $\left(33.52 \mathrm{nmol} \mathrm{g}^{-1}, \mathrm{FW}\right)$ while highest decrease was observed in boric acid (BA-2) (22.51 nmol g- ${ }^{-1}$ FW) as compared to control (26.77 nmol g-1 FW).

Tomato leaves showed $41.88 \mathrm{nmol} \mathrm{g}^{-1}$ on fresh weight basis during the second year treatments. During this stage, all treatments, except TB-1, reflected an increase in the proline amount as compared to the control. The first dose caused a decrease in the proline content in the leaves $\left(39.84 \mathrm{nmol} \mathrm{g}^{-1}\right)$. The following two doses increased the proline content to 48.23 and $46.70 \mathrm{nmol} \mathrm{g}^{-1}$, respectively. Highest amount of proline was observed in BA-1 treated plants $\left(63.70 \mathrm{nmol} \mathrm{g}^{-1}, \mathrm{FW}\right)$. The tested three commercial pesticides i.e. LA (42.09 $\left.\mathrm{nmol} \mathrm{g}^{-1}\right), \mathrm{ZO}$ $\left(47.31 \mathrm{nmol} \mathrm{g}^{-1}\right)$ and AD (42.19 nmol g $\left.\mathrm{g}^{-1}\right)$ caused an increase in proline content on fresh weight basis, where Zoom caused the highest increase (seen in Table 4).

By looking the whole picture of 2010, boric acid put the plant into slight oxidative stress with increase in its amount. On the other hand, proline amount in the tarimbor treated plant leaves was found less than the control in all three doses. It means that tarimbor is more suitable than boric acid in case of oxidative stress. In the second year of the study, all treatments, except 
TB-1, put the plants intro oxidative stress by increasing the proline amount as compared to the control.

Ardiç [37] studied the oxidative stress in two varieties of Cicer arietinum L. i.e. cv. "Gökçe" and "Küsmen 99" by using boron. When the plant was treated with $400 \mathrm{mmol}$, the amount of proline in the plant was increased three times in "Gökçe". In a previous study [38] on Solanum lycopersicum L., we applied 4 various insecticides. Leaf free proline content increased in the leaves of tomato plants sprayed with increasing doses of pesticides. Proline content was highest in the leaves of plants sprayed with the highest dose of thiamethoxam. Karabal et al. [39] studied two types of barleys i.e. hamidiye (boron sensitive) and anadolu (boron resistant). They did not found any correlation of boron with the proline amount.

Table 4. Effect of pesticides and different boron compounds on the Proline and MDA ( $\left.\mathrm{nmol} \mathrm{g}^{-1} \mathrm{FW}\right)$ contents (year 2010\&2011)

\begin{tabular}{c|cc|cc}
\hline \multirow{2}{*}{ Treatments } & \multicolumn{2}{|c|}{2010} & \multicolumn{2}{c}{2011} \\
\cline { 2 - 5 } & Proline & MDA & Proline & MDA \\
\hline C & $26.77 \mathrm{a}$ & $1.65 \mathrm{abc}$ & $41.88 \mathrm{c}$ & $0.87 \mathrm{a}$ \\
BA-1 & $25.67 \mathrm{a}$ & $2.07 \mathrm{a}$ & $63.70 \mathrm{a}$ & $0.92 \mathrm{a}$ \\
BA-2 & $22.51 \mathrm{a}$ & $1.95 \mathrm{a}$ & $55.71 \mathrm{ab}$ & $0.99 \mathrm{a}$ \\
BA-3 & $27.37 \mathrm{a}$ & $1.33 \mathrm{bc}$ & $45.26 \mathrm{bc}$ & $0.82 \mathrm{a}$ \\
TB-1 & $33.52 \mathrm{a}$ & $1.38 \mathrm{bc}$ & $39.84 \mathrm{c}$ & $0.88 \mathrm{a}$ \\
TB-2 & $30.7 \mathrm{a}$ & $1.96 \mathrm{a}$ & $48.23 \mathrm{bc}$ & $0.91 \mathrm{a}$ \\
TB-3 & $25.92 \mathrm{a}$ & $1.22 \mathrm{c}$ & $46.70 \mathrm{bc}$ & $0.98 \mathrm{a}$ \\
LA & $22.85 \mathrm{a}$ & $1.3 \mathrm{c}$ & $42.09 \mathrm{c}$ & $0.92 \mathrm{a}$ \\
ZO & $29.68 \mathrm{a}$ & $1.83 \mathrm{ab}$ & $47.31 \mathrm{bc}$ & $0.98 \mathrm{a}$ \\
AD & $25.92 \mathrm{a}$ & $1.62 \mathrm{abc}$ & $42.19 \mathrm{c}$ & $0.90 \mathrm{a}$ \\
\hline
\end{tabular}

Note: values followed by different letters, in the same column, are significantly different at $p \leq 0.05$.

Malondialdehyde (MDA) was also analyzed in the leaves of L. esculentum for two years. During the first year study, an increase of boric acid and tarimbor dose decreased MDA while during second year; both increases and decreases were observed in the MDA amount. Highest MDA was found in BA-1 $\left(2.07 \mathrm{nmol} \mathrm{g}^{-1}, \mathrm{FW}\right)$ treated plants while the least amount of MDA $\left(1.22 \mathrm{nmol} \mathrm{g}^{-1}, \mathrm{FW}\right)$ was found in TB-3 as compared to the control $\left(1.65 \mathrm{nmol} \mathrm{g}^{-1}, \mathrm{FW}\right)$. During second year analyses, lipid peroxidation test showed $0.87 \mathrm{nmol} \mathrm{g}^{-1}$ malondialdehyde (MDA) in tomato leaves. Highest MDA was found in BA-II ( $\left.0.99 \mathrm{nmol} \mathrm{g}^{-1}, \mathrm{FW}\right)$ (seen in Table 4).

MDA decreased during both years analyses as a whole after the boron treatment when compared to the control, but the decrease was statistically not significant $(\mathrm{p}<0.05)$. It means that the treatments did not show any damage to the cell membrane. In pesticide treatments, MDA was increased in all pesticides applied as compared to the control.

Zabalza et al. [40] applied imidazolinone herbicide over beans and observed an increase in the MDA amount in the leaves. Our results show parallel behavior with this study in case of externally applied dose. In another study, oxyfluorfen and diphenyl ether (herbicides) were used over wheat and barley leaves [41]. On comparison with the control, the workers found the decrease in the amount of MDA. Pogosyan et al. [42] used 2,4-dichlorophenoxyacetic acid and 2,4,5-trichlorophenoxyacetic acid over Pisum sativum and observed less MDA than in the leaves of control. These results are in contrast of our study.

\subsection{Antixodative enzymes}

There are various enzymes in plants that can increase or decrease during the stress conditions. Most important enzymes are superoxide dismutase (SOD), ascorbate peroxidase 
(APOD), peroxidase (POD) [43] and catalase (CAT) that makes the antioxidative defense mechanism [44]. APOD and CAT cleans $\mathrm{H}_{2} \mathrm{O}_{2}$ from chloroplasts and mitochondria. SOD removes superoxide anions while POD catalyze the breaking hydrogen peroxide.

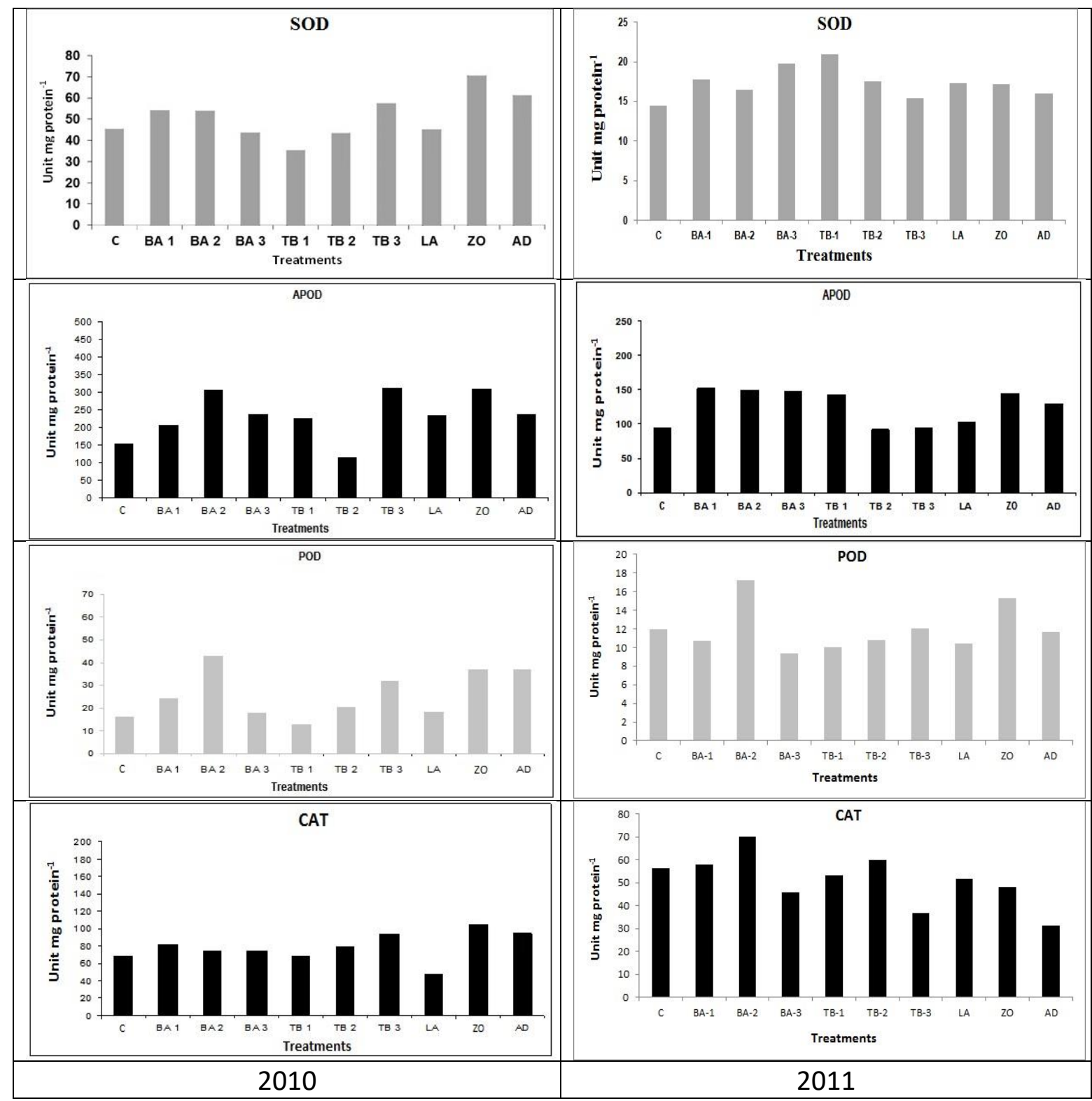

Figure 1. Superoxide dismutase (SOD), ascorbate peoxidase (APOD), peroxidase (POD) and catalase (CAT) levels of tomato plants sprayed with various levels of pesticides and boron compounds.

During 2010 and 2011, protein per gram amount of the stated enzymes were increased as compared to the control group. In 2010, highest SOD amount was found in plants treated with $\mathrm{ZO}$ i.e. 70.35 unit $\mathrm{SOD} / \mathrm{mg}$ protein while tarimbor I treatment caused the highest decrease in the SOD amount i.e. 35.21 unit SOD/mg protein (control: 45.23 unit SOD/mg protein). Results obtained for APOD, POD and CAT were also analogues. Similar results were also obtained for SOD and POD by Kaya et al. [45] while studying tomatoes. In this study in general, pesticide treatment to $L$. esculentum caused an increase in all enzyme amounts. However, treatment of boron, if not at toxic levels, do not show notable stress. Tepe and Aydemir [46] applied boron to lentil and barley and found higher amounts of APOD and CAT. That is why the SOD amount was found less as compared to the control group. During 2011, all the pesticide treatments increased the amount of plant enzymes except CAT, which was very near to the control amount. 


\section{CONCLUSION}

In this study, Lycropersicum esculentum L. was studied for its oxidative stress by using pesticides and boron compounds. Boron showed toxicity even if slight amount is higher than the required to the plant. So it is suggested to analysis boron amount in the soil before its external use as a fertilizer. We utilized boron and pesticides in the prescribed amount that is why no notable toxicity was observed. It was also found that if the boron amount is less than the required amount, the yield will be less. The use of pesticides is not too much important if the area has no disease spread in tomatoes. We observed slight decrease in the total tomatoes yield after the use of pesticides while the control group did not get any disease.

\section{Acknowledgment}

We are thankful to the National Boron Research Institute, Ankara, Turkey (BOREN) (project No: BOREN 2009/Ç0225) and BAP (Scientific Research Projects) Muğla Sitk1 Koçman University Muğla Turkey (Project No: BAP-2011/15) for their financial support.

\section{ORCID}

\section{Mahmut Yildıztekin (D) https://orcid.org/0000-0002-0206-0117}

\section{REFERENCES}

[1] Lichtenthaler, H.K. (1996). Vegetation stress: An introduction to the stress concept in plants . J Plant Physiol, 148, 4-14.

[2] Dhaliwal, G.S., Singh, B. (2000). Pesticides and environment. Commonwealth Publishers, New Delhi, 439 pp.

[3] Parween, T., Jan, S., Fatma, T. (2011). Alteration in nitrogen metabolism and plant growth during different developmental stages of green gram (Vigna radiata L.) in response to chlorpyrifos. Acta Physiol. Plant., 33, 2321-2328.

[4] Xia, X.J., Huang, Y.Y., Wang, L., Huang, L.F., Yu, Y.L., Zhou, Y.H., Yu, J.Q. (2006). Pesticides-induced depression of photosynthesis was alleviated by 24-epibrassinolide pretreatment in Cucumis sativus L. Pest. Biochem. Physiol., 86, 42-48.

[5] Kuhara, T.P., Stivers-Youngb, L.J., Hoffmann, M.P., Taylor, A.G. (2002). Control of corn flea beetle and stewart's wilt in sweet corn with imidacloprid and thiamethoxam seed treatments. Crop Protec., 21, 25-31.

[6] Fitzgerald, J. (2004). Laboratory bioassay and field evaluation of insecticides for control of Anthonomus rubi, Lygus rugulipennis and Cheatosiphon fragaefolii, and effects on beneficial species in UK strawberry production. Crop Protec., 23, 801-809.

[7] Putter, I., MacConnell, J.G., Preiser, F.A., Haidri, A.A., Ristich, S.S., Dybas, R.A. (1981). Avermectins: Novel insecticides acaricides and nematicides from a soil microorganism. Experientia., 37, 963-964.

[8] Liu, T.X. (2003). Effects of a juvenile hormone analog, pyriproxifen, on Thrips tabaci (Thysanoptera: Thripidae). Pest. Manag. Sci., 59, 904-912.

[9] Liu, T.X., Stansly, P.A. (2004). Lethal and sublethal effects of two insect growth regulators on adult Delphastus catalinae (Coleoptera: Coccinellidae), a predator of whiteflies (Homoptera: Aleyrodidae). Biol. Cont., 30(2), 298-305.

[10]Ren, H.X., Wang, Z.L., Chen, X., Zhu, Y.L. (1999). Antioxidative responses to different altitudes in Plantagomajor. Environ. Exp. Bot., 42, 51-59.

[11]Zaefyzadeh, M., Quliyev, R.A., Babayeva, S., Abbasov, M.A. (2009). The effect of the interaction between genotypes and drought stress on the superoxide dismutase and chlorophyll content in durum wheat landraces. Turk. J. Biol., 33, 1-7.

[12] Banerjee, B.D., Seth V., Bahattacharya, A. (1999). Biochemical effects of some pesticides 
on lipid peroxidation and free-radical scavengers. Toxicol. Lett., 107, 33-47.

[13] Nicholas, J., Wood, J.S. (2001). Catalase and superoxide dimutase activity in ammoniaoxidising bacteria. FEMS Microbiol. Ecol., 38,53-58.

[14]Chen, Q., Zhang, M., Shen, S. (2010). Effect of salt on malondialdehyde and antioxidant enzymes in seedling roots of Jerusalem artichoke (Helianthus tuberosus L.). Acta Physiol. Plant., 33, 273-278.

[15]Faize, M., Burgos, L., Faize, L., Piqueras, A., Nicolas, E., BarbaEspin, G., ClementeMoreno, M.J., Alcobendas, R., Artlip T., Hernandez, J.A. (2011). Involvement of cytosolic ascorbate peroxidase and $\mathrm{Cu} / \mathrm{Zn}$-superoxide dismutase for improved tolerance against drought stress. J. Exp. Bot., 62, 2599-2613.

[16] Tuluce Y, Celik I. (2006). Influence of subacute and subchronic treatment of abcisic acid and gibberellic acid on serum marker enzymes and erythrocyte and tissue antioxidant defense systems and lipid peroxidation in rats. Pest Biochem Physiol., 86, 85-92.

[17]Brown, P.H., Shelp, B.J. (1997). Boron mobility in plants. Plant and soil, 193(1-2), 85101.

[18]Loomis W.D. , Durst, R.W. (1992). Chemistry and biology of boron, BioFactors (Oxford, England), 3(4), 229-239.

[19] Strain, H.H., Svec, W.A. (1966). Extraction separation estimation and isolation of the Chlorophylls. In: The Chlorophylls Academic Press, Vernon, L.P., Seely G.R. (Eds.): New York., pp 21-65.

[20] Bates, L.S., Waldren, R.P., Teare, I.D. (1973). Rapid determination of free proline for water stress studies. Plant Soil., 39, 205-207.

[21] Giannopolitis C.N., Ries S.K. (1977). Superoxide Dismutases Occurrence in Higher Plants. Plant Physiol., 59, 309-314.

[22] Cakmak, I., Horst, W.J. (1991). Effect of aluminium on lipid peroxidation, superoxide dismutase, catalase, and peroxidase activities in root tips of soybean (Glycine max). Physiol Plantarum., 83, 463-468.

[23] Bergmeyer N. (1970). Methoden Der Enzymatischen Analyse, Berlin: Akademie Verlag, 1, 636-47.

[24] Nakano, Y., Asada, Y. (1981). Purification of Ascorbate Peroxidase From Spinach Chloroplasts: Its Inactivation in Ascorbat Depleted Medium and Reactivation by Monodehydro ascorbate Radical. Plant Cell Physiol., 28, 131-135.

[25]Herzog, V., Fahimi, H. (1973). Determination Of The Activity Of Peroxidase. Anal Biochem., 55, 554-562.

[26]Bradford, M.M. (1992). A Rapid And Sensitive Method For The Quantitation Of Micrograms Quantities Of Protein Utilizing The Principle Of Protein-Dye Binding. Anal Biochem. 44, 276-287.

[27] Madhava Rao K.V., Sresty T.V.S. (2000). Antioxidative Parameters in The Seedlings Of Pigeonpea (Cajanus Cajan L. Millspaugh) in Response to Zn and Ni Stresses. Plant Sci. 157, 113-28.

[28]Lindsay, W.L., Norvell, W.A. (1978). Development of a DTPA Soil Test for Zinc, Iron, Manganese and Copper. Soil Sci. Soc. Am. J., 42, 421-428.

[29] Thomas, G.W. (1982). Exchangable cations. P. 159-165. Chemical and Microbiological properties. Agronomy Monograph No. 9 (2nd Ed) ASASSSA. Madison, Wisconsin. USA.

[30] Knudsen, D., Peterson, G.A., Pratt, P.F. (1982). Lithium, sodium and potassium. Methods of soil analysis. Part 2. Chemical and Microbiological Properties. Agronomy Monograph No:9 (2. Ed.). ASA-SSSA. P. 225-246 Madison-Wisconsin, USA. 
[31]Bingham, F.T. (1982). Boron. Methods of Soil Analysis. Part 2, Second edition American society of Agronomy, Inc., Wisconsin USA, pp 431-447.

[32] Kacar, B., Fox, R.L. (1966). Boron status of some Turkish soils. University of Ankara, Yearbook of the faculty of Agriculture, Ankara, 9-11.

[33] Wang, J.Z., Tao, S.T. Qi, K.J., Wu, J., Wu, H.Q., Zhang, S.L. (2011). Changes in photosynthetic properties and antioxidativesystem of pear leaves to boron toxicity. African Journal of Biotechnology, 10(85), 19693-19700.

[34] Tort, N., Dereboylu, A.E. (2003). Anadolu. J. of AARI, 13 (1), 142-157.

[35] Öztürk, İ., Tort, N. (2004). The Effect of Fungicide Application on Some Photosynthetic Pigment Substances, Plant Hormones and the Amounts of Protein in the Leaves of Tomato (Lycopersicon esculentum Mill.). C. U., J Nat and Applied Sci, 25(1), 7-19.

[36] Rao, G.G., Rao, G.R. (1981). Pigment composition and chlorophyllase activity in Pigeon pea (Cajanus indicus Spreng.) and gingelly (Sesamum indicum L.) under $\mathrm{NaCl}$ salinity. Indian J.Exp. Biol., 19, 768-770.

[37] Ardiç, M. (2007). Effects of Boron Toxicity on Some Physiological and Biochemical Characteristics of Chickpea (Cicer arietinum L.), Eskişehir Osmangazi Uni., Ph. D. Thesis, Graduate School of Natural and Applied Sciences, Department of Biology, 83p.

[38] Yildiztekin, M., Kaya, C., Tuna, A.L., Ashraf, M. (2015). Oxidative stress and antioxidative mechanisms in tomato (Solanum lycopersicum L.) plants sprayed with different pesticides, Pakistan Journal of Botany (Pak J Bot), 47(2), 717-721.

[39] Karabal, E., Yücel, M., Öktem, H.A. (2003). Antioxidant response soft tolerant and sensitive barley cultivars to boron toxicity. Plant Science, 164, 925-933 p.

[40] Zabalza, A., Gaston, S., Sandalio, L.M., Rio, L.A., Royuela, M. (2007). Oxidative stres is not related to the mode of action of herbicides that inhibit acetolactate synthase., Environmental and Experimental Botany, 59(2), 150-159.

[41] Choi, J.S., Lee, H.J., Hwang, I.T., Pyon, J.Y., Cho, K.Y. (1999). Differential susceptibilities of wheat and barley to Diphenyl eter herbicite Oxyfluorfen. Pesticide Biochemistry and Physiology., 65(1), 62-72.

[42] Pogosyan, S.I, Shevchenko, N.V., Merziyak, M.N. (2003). Situmilation of nadphdependent lipid peroxidation by 2,4- dichlorophenoxyacetic acid, 2.4.5trichchlorophenoxyacetic acid and diquat in microcomes isolated from Pisum sativum. Plant Science letters, 37, 69-72.

[43] Gaspar, T., Penel, C., Hagege, D., Greppin, H. (1991). Peroxidases in Plant Growth Differentiation And Development Processes, Univ. M. Curie-Sklodowska, Lublin, Poland And Univ., Geneva, Switzerland.

[44] Dionisio-Sese, M.L., Tobita, S. (1998). Antioxidant responses of rice seedlings to salinity stress. Plant Sci., 135, 1-9.

[45] Kaya, C., Tuna A.L., Dikilitaş, M., Ashraf, M., Köşkeroğlu, S., Güneri, M. (2009). Supplementary phosphorus can alleviate boron toxicity in tomato. Scientia Horticulturae, $121,284-288$.

[46] Tepe, M., Aydemir, T. (2011). Antioxidant responses of lentil and barley plants to boron toxicity under different nitrogensources. African Journal of Biotechnology, 10(53). 10882-10891. 